\title{
The Effect of Muslim Religiosity and Innovation Capability on Firm Survival: A Study on Small Enterprises During the Covid-19 Pandemic
}

IQTISHADIA

13,2

\author{
Humam Santosa Utomo \\ University of Pembangunan Nasional Veteran, Yogyakarta \\ humam.santosautomo@upnyk.ac.id
}

\begin{abstract}
The covid-19 pandemic felt its impact on small businesses in Bantul, Yogyakarta. Internal strengths and external challenges participate in determining firm survival. This research aimed to examine and analyze the effect of Muslim religiosity and innovation capability on firm survival. Also, this research investigated the moderation role of environmental uncertainty on the effect of Muslim religiosity and innovation capability on firm survival. The study was conducted during the covid-19 pandemic. The analysis unit of this research was the owners of processed food small enterprises fostered by the regional government of Bantul Regency, Yogyakarta. The number of respondents involved in this research was 120 Muslim entrepreneurs. Data were collected using closed questionnaires distributed online, than processed using SEM-WarpPLS. The results showed that the Muslim religiosity and innovation capability significantly affected firm survival. Environmental uncertainty significantly weakened the effect of innovation capability on firm survival. However, environmental uncertainty insignificantly weakened the effect of Muslim religiosity on firm survival. These research results indicate the importance of religious formation for small entrepreneurs in this crisis time. Innovation is also important in increasing the firm survival of small companies during the covid-19 pandemic. The government must provide religious assistance to small entrepreneurs, both in normal conditions and in conditions of crisis to increase business enthusiasm. The government should facilitate access to information for small entrepreneurs so that they can carry out marketing innovations in order to access a wider market.
\end{abstract}

Keywords: Muslim religiosity, Innovation capability, Firm survival, Environmental uncertainty, Small enterprise.

\section{INTRODUCTION}

Small and Medium Enterprises (SMEs) is proven able to survive during the 1997-1998 monetary crisis and become the economic backbone of a country (Sitharam \& Hoque, 2016). The Covid-19 pandemic today increasingly have a great impact on Indonesia's economy, affecting SME performance. SME access to markets is getting obstructed due to the situation demanding business Dor:10.21043/iqtishadia.v13i2. 39626 
IQTISHADIA

13,2

centers to reduce or even stop their business activities. Environmental uncertainty is felt as a hampering factor for SMEs in increasing their performance and existence. This research was directed to analyze the effects of internal and external factors on firm survival. The research results of in China showed that small enterprises generally managed individually are proven to have a higher survival level (Yu Cao, 2012). This result is necessarily re-examined for the covid-19 pandemic cases in Indonesia.

Small enterprises engaged in the production of processed food are experiencing impacts of Covid-19, including those in Bantul, Yogyakarta. The results of observation and interview with the respondents (processed food entrepreneurs) in the area on April 15-16 $6^{\text {th }}, 2020$ showed that they were highly impacted by the Corona Virus outbreak. However, not all SMEs are negatively affected by this situation. There are various impacts emerging, such as decreased sales, inefficient production due to increased raw material costs, delayed product distribution, and even forced business closure or bankruptcy. There are many factors influencing the performance of small enterprises, covering internal and external factors (Ontorael et al., 2017). Internal factors such as religiosity and innovation capability. Spiritual power is needed when disasters or bad situations happen because it is estimated to have impact on mentality or mental endurance. In the context of this research, weak mentality can lead to high stress levels so it has implications for causing mistakes in making decisions and small enterprise behavior in managing the business. Meanwhile, innovation capability directs small enterprise strategies in serving changing market behavior.

Studies on firm survival in the crisis time is still limited (Karadag, 2016). Therefore, the researcher were interested to carry out this research with the aim at finding solutions for small enterprises in this crisis time so as to minimize the number of bankrupt small enterprises. Wahab et al. (2018) conducted a study of Islamic religious practices as a moderator of the success of SMEs. Mohd (2014) and Mohamad et al. (2018) revealed that Islamic values are the key to the success of SMEs. Tahir \& Abdul (2013) predict that religious orientation is related to company performance. Ghouri et al. (2018) found that religious orientation has a significant impact on employees' competitive behavior. Meanwhile, Baqutayan (2011) examined the relationship between religiosity and stress levels. Researcher see that there is still a research gap that links religiosity to firm survival.

Studies that examine the relationship between innovation and performance have been carried out (Battor \& Battor, 2010; Sulistyo \& 
Siyamtinah, 2016). Research examining the effect of innovation on firm The Effect of survival is still limited (Ortiz-Villajos \& Sotoca, 2018). Research on the effect of innovation on firm survival, especially in times of crisis is needed. Muslim Religiosity and Innovation Environmental uncertainties that occur during times of crisis have also not been studied as firm survival inhibiting variables, so they are research gaps in previous studies.

This research closes the research gap so that it is a research novelty. Novelty research shows the relationship between religiosity and firm survival as well as the role of environmental uncertainty as an obstacle to firm survival. In addition, this study was carried out on pandemic covid-19 so that it gives a different phenomenon under normal conditions.

The objective of this research was to examine and analyze the effect of religiosity and innovation capability on firm survival levels as well as to test the effect of environmental uncertainty as the moderator. There has been only a small number of research examining the effects of spirituality and innovation factors on firm survival in the crisis time, especially on small enterprises.

\section{LITERATURE REVIEW}

\section{Religiosity}

Religiosity shows the extent to which someone is involved in their religion and the extent to which someone integrates religion or refers to transcendence in their daily lives (Saroglou, 2010). El-Menouar (2014), Ghorbani et al. (2014), Kusumawati et al. (2020), Mahudin et al. (2016), and Olufadi (2017) has developed a measurement of Muslim religiosity but with a different approach. There is no uniformity in measuring religiosity so measurements can be made according to the opinion of each researcher.

\section{Innovation Capability}

Innovation is an important organizational capability, because the success of new products is an engine of growth that has an impact on increasing sales, profits, and the power of competition (Battor \& Battor, 2010). Innovation is a process that starts with an idea, which is the result of developing findings and introducing new products, new processes and services in the market (Thornhill, 2006).

Innovation is a process and/or outcome of undertaking changes in an organizational conduct by pursuing new activities, routines and processes 
IQTISHADIA in service to enhance the delivery of significant benefits to customers, the 13,2 release of capabilities within the service firm and the competitive posture of the firm (Anning-Dorson, 2017). Thus, Innovation Capability in the context of this study is the ability of SMEs to develop new products or new services in accordance with market demand.

\section{Firm survival}

Firm survival shows the level of resilience of the company in the face of competition and environmental changes. Changes in the environment that drastically drained the company's resources quickly and it threatened the company's survival. The implication is a decrease in performance until bankruptcy. This study measures firm survival during the Covid-19 pandemic crisis based on company operations (operating normally, declining operational, and stopping operating completely). According to the resourcebased view, the survival and growth of a company is determined by the company's resources and capabilities (Barney, 1991). Each company has unique resources, both tangible and intangible resources (Shin et al., 2017). Utilization of resources is maximized to improve performance and firm survival.

\section{Environmental Uncertainty}

Environmental Uncertainty refers to the perception of the uncertainty of environmental variables that have an impact on organizational performance (Miller, 1993). Environmental Uncertainty is caused by changes in market, technology, and regulatory environment (Bstieler, 2005; Engau \& Hoffmann, 2009). In the context of this research, only two indicators have been developed namely changes in the market environment and regulations. Market uncertainty refers to market uncertainty, changes in market structure and the level of competition with respect to industry (Bstieler, 2005). Regulatory uncertainty refers to the uncertainty of the actions of regulatory agencies that create and enforce regulations and policies (Engau \& Hoffmann, 2009).

Environmental uncertainty makes it difficult for SMEs to understand the rapidly changing environment so that SMEs have difficulty making strategic decisions. Information needed to make comprehensive decisions may not be available (Fredrickson \& Mitchell, 1984). This lack of information together with the uncertainty of environmental variables can cause serious mistakes in decision making. Likewise, innovations created by SMEs do not 
necessarily have a positive impact on performance. As such, SMEs need to continue aligning strategies to accommodate the ongoing environmental Muslim Religiosity changes that are full of uncertainties.

\section{Conceptual Framework and Hypothesis}

Religiosity and Firm Survival

Wahab et al. (2018) revealed that the practice of Islamic religion is a moderator of the success of SMEs. Mohd et al. (2014) and Mohamad et al. (2018) also revealed that Islamic values are the key to the success of SMEs. Tahir \& Abdul (2013) predict that religious orientation is related to company performance. Ghouri et al. (2018) found that religious orientation has a significant impact on employees' competitive behavior thereby increasing firm survival. Meanwhile, Baqutayan (2011) found a relationship between religiosity and stress levels. The higher the religious orientation, the lower the stress level. Someone who is stressed is predicted to have difficulty in making rational business decisions because the level of stress affects the quality of decision making. Errors in making business decisions have implications for business continuity. Religiosity is also predicted to give spirit in running a business. As a Muslim, giving work to others is worth worshiping so that a Muslim entrepreneur has a high spirit to develop and maintain the existence of his business. Thus, religiosity is an antecedent factor that affects firm survival.

Hypothesis 1. Religiosity has a significant effect on firm survival

\section{Innovation Capability and Firm Survival}

Innovation capability is one of the company's resources created through creative human resources. The resource-based view explains that company resources have implications for the survival of the company (Barney, 1991). Products and services that are unique in accordance with market demand are responded positively by consumers so that the company has high competitiveness. Studies conducted by Battor \& Battor (2010) show there is a strong relationship between innovation ability and performance. Sulistyo \& Siyamtinah (2016) concluded that SME innovation had a significant positive effect on SME performance. Ortiz-Villajos \& Sotoca (2018) found that innovation has the opportunity to improve firm survival. Bamfo and Kraa (2019) found that innovation maximizes SME performance. Soininen et al. (2012) showed that innovation is needed during an economic crisis to reduce the impact of the crisis on performance so that SMEs have high survival. 
IQTISHADIA Hypothesis 2. Innovation capability has a significant effect on firm survival

Environmental Change, Religiosity, Innovation Capability, and Firm Survival

During the Covid-19 pandemic, environmental changes occurred rapidly in both supply and market terms. Strategic choice theory reveals that companies actively make decisions quickly in response to changing environments so that they are still able to grow and survive (Mellahi \& Wilkinson, 2004). SMEs must have resilience in the face of unexpected environmental changes (Ayala \& Manzano, 2014). However, rapid changes make it difficult for SMEs to accelerate strategy. SMEs have difficulty making new innovations in an uncertain environment. The acceleration of SMEs in implementing an innovation strategy is not proportional to the rapid market changes caused by uncertain regulations. This of course also impacts on firm survival. Thus the Environmental Uncertainty is predicted to weaken the influence of religiosity and innovation capability on firm survival. Based on this description, the specific hypothesis is formulated as follows:

Hypothesis 3. Environmental uncertainty weakens the effect of religiosity on firm survival

Hypothesis 4. Environmental uncertainty weakens the effect of innovation capability on firm survival

\section{RESEARCH METHOD}

\section{Data Collection and Sample}

Researcher used survey methods to collect data by distributing questionnaires online to respondents. The sample of this study is a small-scale Muslim entrepreneur in the field of processed food in Bantul, Yogyakarta, which is incorporated in the business group "Agro Mirasa Boga". The criteria used are processed food producers that have operated in the field of processed foods for at least the last 3 years. The data was collected at the pandemic covid-19 in March-April 2020. Researchers distributed 130 questionnaires to members of the "Agro Mirasa Boga" business group that met the criteria and collected as many as 120 completed questionnaires. 


\section{Instrument and Data Analysis}

The instrument used to collect research data was a questionnaire containing a set of questions or statements related to respondent demographic data and research variable items. This study uses literature studies to measure all constructs in this study. Muslim religiosity variables are measured by three dimensions (Faith, Islam, Ikhsan) which were adapted from (Mahudin et al., 2016). Innovation capability is measured using indicators developed by Thornhill (2006). Firm survival is done by comparing the level of surgery at the time of the pandemic covid-19 with the level of surgery before the pandemic covid-19. Firm survival is measured using an ordinal scale consisting of 3 scales: normal company operations; the company's operating level has decreased; not operating. Environmental uncertainty was adapted from the indicators of Bstieler (2005) and Engau \& Hoffmann (2009). This research is perceptional so testing research instruments is needed. Validity and reliability tests were carried out before using the instrument for data collection by testing 30 respondents. Data were analyzed using SEMWarpPLS.

\section{RESULTS}

\section{Results of Instrument Validity and Reliability Tests}

Table 1 shows that the correlation coefficient for all items is more than 0.30 and the Cronbach's a value in each variable used in this research is beyond o.6. It can be interpreted that all items of question are proven to be valid and reliable to use as a tool of data collection.

\section{Profile of Respondents}

Table 2 shows the characteristics of the respondents. Most respondents were female (65\%). The age of respondents is dominated by entrepreneurs with the age group 26-45 years (58.33\%) and most companies are $>10$ years old (54.17\%). Based on marital status, most respondents were married (79.17\%).

\section{Final Structural Model}

Measurement of model fit and quality indices refers to the WarpPLS analysis tool (Kock, 2015). The measurement results show the followings. Average Path Coefficient (APC) was 0.354, p < 0.001; average R-squared (ARS) was 1.437, p < 0.001; average adjusted R-square (AARS) was 1.233, p <
The Effect of

Muslim Religiosity and Innovation

185 
IQTISHADIA

13,2

o.oo1; average block VIF (AVIF) was 4.285, acceptable if $\leq 5$; average full collinearity VIF (AFVIF) was 4.312, acceptable if $\leq 5$; Tenenhaus GoF (GoF) was 0.703, acceptable if $\geq 0.36$; Sympson's Paradox Ratio (SPR) was 1,000, acceptable if $\geq 0.7$; Statistical Suppression Ratio (SSR) was 1,000, acceptable if $\geq 0.7$; Nonlinear Bivariate Causality Direction Ratio (NLBCDR) was 0.782, acceptable if $\geq 0.7$. These results indicate that the model is supported by good data and has quality indicators that meet the requirements in the WarpPLS.

\section{Hypothesis Testing}

Hypothesis 1 states that religiosity influences firm survival. The results (Table 3 ) show that $p$ value is $<0.000(<0.05)$, so hypothesis 1 is accepted. Positive coefficients indicate that religiosity has a significant positive effect on firm survival.

Hypothesis 2 states that innovation capability influences firm survival. The results (Table 3 ) show that $p$ value is $<0.000(<0.05)$, so hypothesis 2 is accepted. Positive coefficients indicate that innovation capability has a significant positive effect on firm survival.

Hypothesis 3 states that environmental uncertainty moderates the effect of Muslim religiosity on firm survival. The results (Table 3 ) show that $p$ value is $0.125(>0.05)$, so hypothesis 3 is rejected. Negative coefficients indicate that environmental uncertainty weakens the effect of Muslim religiosity on firm survival.

Hypothesis 4 states that environmental uncertainty moderates the effect of innovation capability on firm survival. The results (Table 3 ) show that $p$ value is $<0.000(<0.05)$, so hypothesis 4 is accepted. Negative coefficients indicate that environmental uncertainty weakens the effect of innovation capability on firm survival.

Figure 1. the conceptual models for the SEM framework

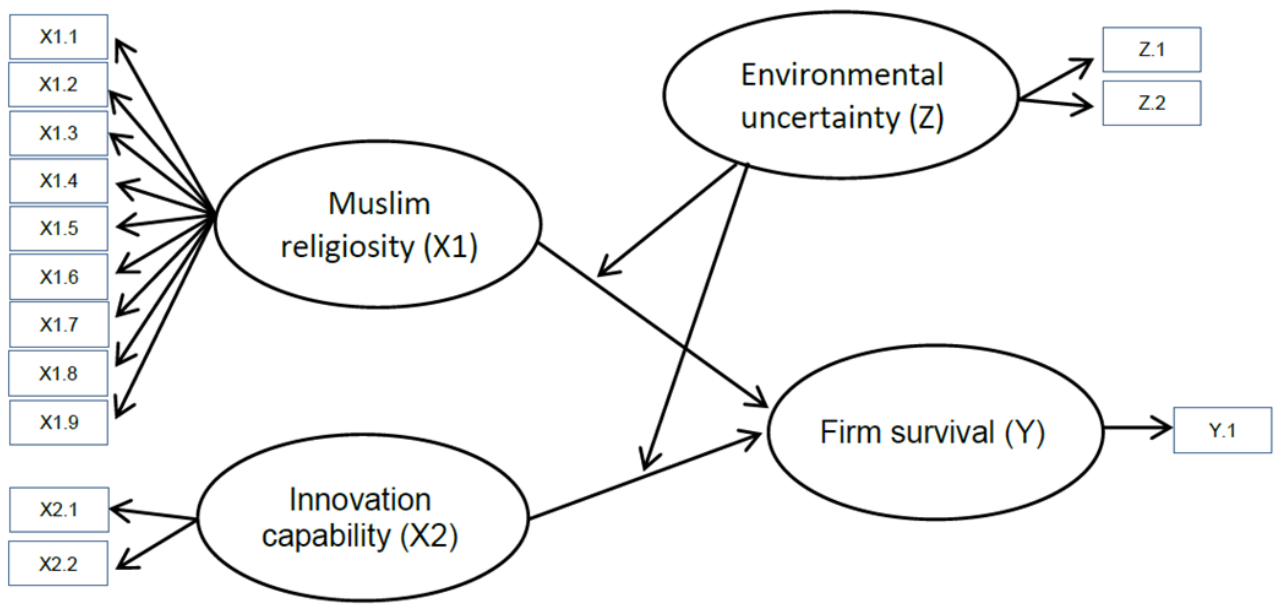


Table 1. Result of instrument validity test

The Effect of Muslim Religiosity and Innovation

\begin{tabular}{|c|c|c|c|}
\hline Variable & Indicator & $\begin{array}{c}\text { Correlation } \\
\text { coefficient }\end{array}$ & Cronbach's a \\
\hline \multirow{9}{*}{$\begin{array}{l}\text { Muslim } \\
\text { Religiosity }\end{array}$} & $\begin{array}{l}\text { At any point of time in life, I can } \\
\text { strengthen my relationship with } \\
\text { Allah }\end{array}$ & 0.554 & \multirow{9}{*}{0.780} \\
\hline & $\begin{array}{l}\text { I strive for both worldly affairs and } \\
\text { the hereafter as advised by Prophet } \\
\text { Muhammad (SAW) } \\
\text { I avoid behavior that will be } \\
\text { punished in the hereafter }\end{array}$ & 0.579 & \\
\hline & $\begin{array}{l}\text { The more knowledge I have, the } \\
\text { more humble I should become }\end{array}$ & 0.870 & \\
\hline & $\begin{array}{l}\text { I strive to follow my aql } \\
\text { (rationality) more than my nafs } \\
\text { (lust) }\end{array}$ & 0.663 & \\
\hline & $\begin{array}{l}\text { I teach my family members the } \\
\text { greatness of Allah. }\end{array}$ & 0.674 & \\
\hline & $\begin{array}{l}\text { I teach my family members to } \\
\text { always remember Allah. }\end{array}$ & 0.883 & \\
\hline & $\begin{array}{l}\text { I feel bad doing something } \\
\text { forbidden even if I know others are } \\
\text { also doing it. }\end{array}$ & 0.767 & \\
\hline & I am pleased with what I have. & 0.613 & \\
\hline & $\begin{array}{l}\text { For fear of Allah I will always tell } \\
\text { the truth. }\end{array}$ & 0.735 & \\
\hline \multirow{2}{*}{$\begin{array}{l}\text { Innovation } \\
\text { Capability }\end{array}$} & $\begin{array}{l}\text { the ability to create new product } \\
\text { innovations }\end{array}$ & 0.465 & \multirow[t]{2}{*}{0.862} \\
\hline & the ability to create new services & 0.569 & \\
\hline \multirow{2}{*}{$\begin{array}{l}\text { Environmental } \\
\text { Uncertainty }\end{array}$} & Market changes & 0.731 & \multirow[b]{2}{*}{0.773} \\
\hline & $\begin{array}{l}\text { Changes in the regulatory } \\
\text { environment }\end{array}$ & 0.779 & \\
\hline
\end{tabular}

Table 2. Characteristics of the sample (\% of respondents, $\mathrm{n}=120$ )

\begin{tabular}{lll}
\hline \multirow{2}{*}{ Gender } & Male & 35.00 \\
\cline { 2 - 3 } & Female & 65.00 \\
\hline Entrepreneur age & $18-25$ years & 25.00 \\
\cline { 2 - 3 } & $26-45$ years & 58.33 \\
\cline { 2 - 3 } & >45 years & 16.67 \\
\hline \multirow{2}{*}{ Firm age } & 3 -6 years & 18.33 \\
\cline { 2 - 3 } & $7-10$ years & 27.50 \\
\cline { 2 - 3 } & $>10$ years & 54.17 \\
\hline Marital status & Single & 20.83 \\
\cline { 2 - 3 } & Married & 79.17 \\
\hline
\end{tabular}


Table 3. Hypothesis testing results

\begin{tabular}{llcccc}
\hline $\begin{array}{c}\text { Relations between variables } \\
\text { (dependent variable } \\
\text { independent variable) }\end{array}$ & Coefficient & p-value & Description & $\begin{array}{c}\text { Hypothesis } \\
\text { Decision }\end{array}$ \\
\hline $\begin{array}{l}\text { Muslim } \\
\text { Religiosity }\end{array}$ & $\begin{array}{l}\text { Firm } \\
\text { survival }\end{array}$ & 0.447 & $<0.000$ & Significant & Accepted \\
\hline $\begin{array}{l}\text { Innovation } \\
\text { capability }\end{array}$ & $\begin{array}{l}\text { Firm } \\
\text { survival }\end{array}$ & 0.372 & $<0.000$ & Significant & Accepted \\
\hline $\begin{array}{l}\text { Environmental } \\
\text { uncertainty }\end{array}$ & $\begin{array}{l}\text { Muslim } \\
\text { Religiosity } \\
\text { X Firm } \\
\text { survival }\end{array}$ & -0.018 & 0.125 & $\begin{array}{c}\text { Not } \\
\text { Significant }\end{array}$ & Rejected \\
\hline $\begin{array}{l}\text { Innovation } \\
\text { capability } \\
\text { X Firm } \\
\text { uncertainty }\end{array}$ & -0.226 & $<0.000$ & Significant & Accepted \\
\hline
\end{tabular}

Figure 2. Final Structural Model

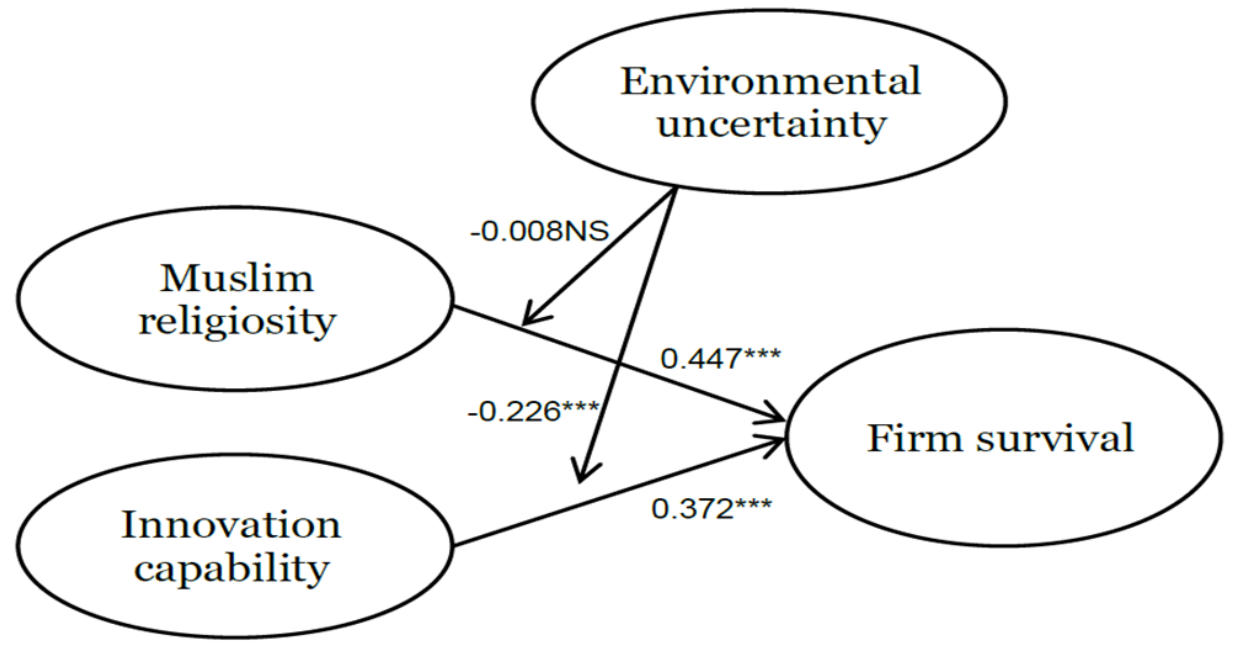

Standardized coefficient, ${ }^{* * *} p<0.01,{ }^{* *} p<0.05, \mathrm{NS}=$ Not Significant

\section{DISCUSSION}

\section{Effects of Muslim Religiosity on Firm Survival}

The results show that Muslim religiosity has a significant effect on firm survival. According to Mohamad et al. (2018), Islamic values drive the success of SMEs. Muslim entrepreneurs who have high religious make their work as worship so they are patient in facing every obstacle of business. They can help others through their business by providing employment. The business goal is not only to pursue profit, but to make others happy through zakat payment. In addition, Muslim entrepreneurs also have the desire to make 

closer to God. In this regard, the determination of faith, Islam, and ihsan Muslim Religiosity strengthen the foundation in running a business. High religious increase and Innovation one's motivation in living life. Driscoll et al. (2019) revealed that spirituality is related to ethical and socially responsible actions. Entrepreneurs who have high spirituality try to maintain their companies to help employees. In the context of the covid-19 pandemic, religiosity helps a person get out of a heavy pressure and strive to maintain the existence of his company. Thus, religiosity affects firm survival in times of crisis.

The results of this study contribute to the theory by presenting empirical evidence from the resource-based view. Company resources have implications for the survival of the company (Barney, 1991). The results of this study support previous research conducted by Wahab et al. (2018), Mohamad et al. (2018), Mohd et al. (2014), and Tahir \& Abdul (2013). Islamic values are the key to the success of SMEs, thereby increasing firm performance. This research has closed the research gap with new finding. Religiosity is proven to have a significant effect on firm survival.

Religiosity is one of the company's resources thereby increasing the company's ability to maintain its existence. Ajuna et al. (2017) and Sarif (2016) revealed that honesty is one aspect of religiosity that makes others believe. This social capital is needed when a crisis occurs so that other parties (investors, creditors, suppliers) are willing to collaborate in overcoming shared problems. SMEs are also honest in offering products to consumers so that consumers trust (Ghoniyah \& Hartono, 2014) and will be respected more in dealing business (Kamaluddin et al., 2018) so that it has implications for the company's future. Kurt et al. (2020) further confirms that spirituality encourages members' commitment to business networks. This result is also beneficial for the government in fostering SMEs. Coaching is not only associated with things that are technical or financial assistance, but mental support is needed. Mental guidance is needed for small entrepreneurs especially when the business environment is unstable which can have an impact on decreasing entrepreneur motivation. Thereby SME coaching should also involve agencies that are related to religious coaching.

\section{Effects of Innovation Capability on Firm Survival}

The results show that innovation capability has a significant effect on firm survival. The results of this study are consistent with the resource-based view 
IQTISHADIA which states that company resources have implications for the survival of the 13,2 company (Barney, 1991). Innovation capability is sourced from the ability of the company's human resources in creating new products and new services. Innovation creates company competitiveness, performance and firm survival. The results of this study are consistent with the results of the studies of Battor \& Battor (2010), Giovannetti et al. (2011), Sulistyo \& Siyamtinah (2016), and Afriyie et al. (2019). Innovation significantly and positively influences the performance of SMEs.

Processed food product innovation and sales services are needed in response to growing market demand. These results indicate that the ability of innovation to improve firm survival during the covid-19 pandemic so that it does not experience bankruptcy. SMEs have high flexibility in creating new products to serve changing market demands. The decline in people's purchasing power is being addressed by small businesses by providing affordable products. Some small entrepreneurs also provide traditional food products that contain nutrients to increase the body's power to covid-19. In addition, innovation is also done through online sales using social media so that it can reach consumers when at home.

\section{Environmental Uncertainty Moderates the Effects of Muslim Religiosity on Firm Survival}

The results of this study indicate that Environmental uncertainty does not significantly weaken the influence of Muslim religiosity on firm survival. Although the influence of moderation is there, but its influence is so weak that it does not significantly affect Muslim religiosity on firm survival. This shows that Muslim religiosity has an important role in increasing firm survival. Muslim religiosity is really needed in times of crisis that have an impact on the sustainability of small business entrepreneurs. The government should provide religious assistance to small entrepreneurs, both in normal conditions and in crisis conditions to improve business spirit. Muslim religiosity is proven to affect attitudes and behavioral intentions (Listyorini et al., 2018). Mental endurance is proven to affect firm survival, even though the business environment is unstable. This research has closed the research gap with new finding. Environmental uncertainty has not been proven to significantly weaken the effect of Religiosity on firm survival. 
This finding shows that environmental uncertainty significantly weakens the and Innovation effect of innovation capability on firm survival. During the covid-19 pandemic, consumers could not access the store so at the beginning of the pandemic, small entrepreneurs had difficulty selling products. The purchasing power of the people has also declined due to reduced employment. Bourletidis \& Triantafyllopoulos (2014) suggest that in times of crisis, small entrepreneurs increase innovation, set new prices, and alliances with suppliers. During the covid-19 pandemic, small entrepreneurs had innovated products by producing varied foods at more affordable prices. Online sales through social media have also been carried out to facilitate the delivery of product information. This is consistent with the opinion of Absah et al. (2018) that social media enhances the performance of small and medium companies. In accordance with Bendickson et al. (2018), companies can take strategic actions to reduce the effects of uncertainty in order to survive. Some small entrepreneurs work together with suppliers to get lower prices and work with the distribution agencies in delivering products to consumers' homes. The innovations that have been made have a significant effect on firm survival, but the effect is weakened by environmental uncertainty. Innovations made by small entrepreneurs are not able to compensate for the rapid changes in the environment. Market changes and changes in regulations issued by the government are considered to weaken the effect of speed of innovation on firm survival. Based on these findings, the government should facilitate access to information for small entrepreneurs, especially small entrepreneurs who are in rural areas so they can access a wider market. This research has closed the research gap with new findings. Environmental uncertainty is proven to significantly weaken the effect of innovation on firm survival.

\section{CONCLUSION}

Based on the results and analysis of this study it can be concluded as follows: Muslim religiosity has a significant effect on the survival of small companies, innovation capability has a significant effect on the survival of small companies, Environmental uncertainty does not significantly weaken the influence of Muslim religiosity on the survival of small companies; and Environmental uncertainty significantly weakens the effect of innovation capability on the survival of small companies. In times of crisis, small 
IQTISHADIA

13,2

companies need mental strength and the ability to innovate in responding to difficulties in doing business so they can survive in times of uncertainty. Spiritual power is proven to increase firm survival despite uncertain situations. The government is expected to play a role in increasing the spiritual strength of small businesses in dealing with crisis conditions. The government also facilitates online marketing for small entrepreneurs in order to expand the market. For example, the government provides free internet data packages for small entrepreneurs.

\section{LIMITATION}

This research has a weakness namely in the measurement of Muslim religiosity. Until now there has been no absolute measurement of religiosity so that measurements with different indicators can have different results. Future studies are expected to use a more comprehensive indicator of religiosity. This study is cross sectional so it cannot compare conditions before and after the covid-19 pandemic. Future studies can compare normal conditions with crisis conditions. Future studies can also examine the effect of religiosity on the level of risk taking of companies in times of crisis according to the study of Jiang et al. (2015).

\section{References}

Absah, Y., Muchtar, Y.C., and Qamariah, I. (2018). The Effect of Intellectual Capital on Business Performance in Micro-, Small-, and Medium Enterprise (MSME) in Medan City. In International Conference of Organizational Innovation (pp. 177-186). https://doi.org/https:// DOI:10.18502/kss.v3i10.3371.

Afriyie, S., Du, J. \& Ibn Musah, A. (2019). Innovation and marketing performance of SME in an emerging economy: the moderating effect of transformational leadership. J Glob Entrepr Res, 9(40). Retrieved from https://doi.org/10.1186/s40497-019-0165-3.

Ajuna, L. H., Nasution, M. Y., \& Yusuf, M. (2017). The Effect of Islamic Religiosity, Islamic Motivation and Islamic Work Ethics To Islamic Leadership Sharia Financial Institutions in Gorontalo Province, Indonesia. IOSR Journal of Humanities And Social Science, 22(8), 60-65. Retrieved from http://doi.org/10.9790/0837-2208176065.

Anning-Dorson, T. (2017). Innovation development in service firms: A threemodel perspective. International Journal of Services and Operations 
Management, 28(1), 64-80. Retrieved from https://doi.10.1504/ IJSOM.2017.085905.

Ayala, J. C., \& Manzano, G. (2014). The Resilience of the Entrepreneur. Muslim Religiosity Influence on the Success of the Business. A Longitudinal Analysis. and Innovation Journal of Economic Psychology, 42, 126-135. Retrieved from http:// doi.org/10.1016/j.joep.2014.02.004.

Bamfo, B.A. and Kraa, J. J. (2019). Market orientation and performance of small and medium enterprises in Ghana: The mediating role of innovation. Cogent Business \& Management, 6. Retrieved from https://doi.org/10.1080/23311975.2019.1605703.

Barney, J. (1991). Firm Resources and Sustained Competitive Advantage. Journal of Management. https://doi. org/10.1177/014920639101700108.

Battor, M., \& Battor, M. (2010). The impact of customer relationship management capability on innovation and performance. Journal of Marketing Management, 26(2010), 842-857.

Bendickson, J., Gur, F. A., \& Taylor, E. C. (2018). Reducing environmental uncertainty: How high performance work systems moderate the resource dependence-firm performance relationship. Canadian Journal of Administrative Sciences. https://doi.org/10.1002/ cjas.1412.

Bourletidis, K., \& Triantafyllopoulos, Y. (2014). SMEs Survival in Time of Crisis: Strategies, Tactics and Commercial Success Stories. Procedia - Social and Behavioral Sciences. https://doi.org/10.1016/j. sbspro.2014.07.092.

Bstieler, L. (2005). The moderating effect of environmental uncertainty on new product development and time efficiency. In Journal of Product Innovation Management. https://doi.org/10.1111/j.07376782.2005.00122.x.

Driscoll, C., McIsaac, E. M., \& Wiebe, E. (2019). The material nature of spirituality in the small business workplace: from transcendent ethical values to immanent ethical actions. Journal of Management, Spirituality and Religion. https://doi.org/10.1080/14766086.2019.1 570474 .

El-Menouar, Y. (2014). The Five Dimensions of Muslim Religiosity . Results of an Empirical Study. Method, Data, Analyses. https://doi. org/10.12758/mda.2014.003.

Engau, C., \& Hoffmann, V. H. (2009). Effects of regulatory uncertainty on corporate strategy-an analysis of firms' responses to uncertainty about 
IQTISHADIA

13,2

194

post-Kyoto policy. Environmental Science and Policy. https://doi. org/10.1016/j.envsci.2009.08.003.

Fredrickson, J. W., \& Mitchell, T. R. (1984). Strategic Decision Processes: Comprehensiveness and Performance in an Industry with an Unstable Environment. Academy of Management Journal. https://doi. org/10.2307/255932.

Ghoniyah, N., \& Hartono, S. (2014). The role of Islamic corporate governance in SMEs to improve the welfare of society. International Journal of Economic Research.

Ghorbani, N., Watson, P. J., Geranmayepour, S., \& Chen, Z. (2014). Measuring Muslim spirituality: Relationships of Muslim experiential religiousness with religious and psychological adjustment in Iran. Journal of Muslim Mental Health. https://doi.org/10.3998/jmmh.10381607.0008.105.

Ghouri, A. M., Khan, N. R., Kareem, O. B. A., \& Shahbaz, M. (2018). Religiosity Effects on Employees in SMEs: An Islamic Country Perspective. Journal of Enterprising Culture. https://doi.org/10.1142/ s0218495818500048.

Giovannetti, G., Ricchiuti, G., \& Velucchi, M. (2011). Size, innovation and internationalization: A survival analysis of italian firms. Applied Economics. https://doi.org/10.1080/00036840802600566.

Jiang, F., Jiang, Z., Kim, K.A., and Zhang, M. (2015). Family-firm risk-taking: Does religion matter? J. Corp. Finance, 33. Retrieved from http:// dx.doi.org/10.1016/j.jcorpfin.2015.01.007.

Kamaluddin, A., Kassim, N., Alam, M. M., \& Samah, S. A. A. (2018). Human capital accountability and construct: Evidence from Islamic microfinance institutions in Malaysia. Global Journal Al-Thaqafah. https://doi.org/10.7187/gjatsi2018-08.

Karadag, D. H. (2016). The Role of SMEs and Entrepreneurship on Economic Growth in Emerging Economies within the Post-Crisis Era: an Analysis from Turkey. Journal of Small Business and Entrepreneurship Development. https://doi.org/10.15640/jsbed.v4n1a3.

Kock, N. (2015). WarpPLS 5.o User Manual, 45. https://doi.org/10.1007/ SpringerReference_28001.

Kurt, Y., Sinkovics, N., Sinkovics, R. R., \& Yamin, M. (2020). The role of spirituality in Islamic business networks: The case of internationalizing Turkish SMEs. Journal of World Business. https://doi.org/10.1016/j. jwb.2019.101034.

Kusumawati, A., Listyorini, S., Suharyono, \& Yulianto, E. (2020). The Role of Religiosity on Fashion Store Patronage Intention 
of Muslim Consumers in Indonesia. SAGE Open. https://doi. org/10.1177/2158244020927035.

Listyorini, S., Kusumawati, A., Suharyono, \& Yulianto, E. (2018). RELIGIOSITY AND FASHION BEHAVIOR AMONG INDONESIAN MUSLIM WOMEN. Russian Journal of Agricultural and SocioEconomic Sciences. https://doi.org/10.18551/rjoas.2018-12.40.

Mahudin, N. D. M., Noor, N. M., Dzulkifli, M. A., \& Janon, N. S. (2016). Religiosity among Muslims: A Scale Development and Validation Study. Makara Human Behavior Studies in Asia. https://doi. org/10.7454/mssh.v20i2.3492.

Mellahi, K., \& Wilkinson, A. (2004). Organizational failure: A critique of recent research and a proposed integrative framework. International Journal of Management Reviews. https://doi.org/10.1111/j.14608545.2004.00095.x.

Miller, K. D. (1993). Industry and Country Effects on Managers' Perceptions of Environmental Uncertainties. Journal of International Business Studies. https://doi.org/10.1057/palgrave.jibs.8490251.

Mohamad, Z., Rahim, M. Z. B. A., Muda, H., Razak, R., Mohamed, M. R., Tambi, A. M., \& Ghani, H. A. (2018). The Interactive Effects of Entrepreneurial Orientation, Islamic Values and Business Success: A Conceptual Study. International Journal of Academic Research in Business and Social Sciences. https://doi.org/10.6007/ijarbss/v8i8/4478.

Mohd, R., Kirana, K., Kamaruddin, B. H., Zainuddin, A., \& Ghazali, M. C. (2014). The Mediatory Effect of Self-efficacy on the Relationship between Religious Values and Entrepreneurial Orientations: A Case of Malay Owner Managers of SMEs in Manufacturing Industry. Procedia-Social and Behavioral Sciences. https://doi.org/10.1016/j. sbspro.2014.04.012.

Nadratun Nafisah Abdul Wahab, Shahrina Othman, Noraini Nasirun@Hirun, Abdullah Abdul Ghani, \& Mohd Rushdi Idrus. (2018). Developing the concept of firm success among Muslim SMEs in Malaysia: A study of Islamic religion practices as moderator. International Journal of Engineering \& Technology.

Olufadi, Y. (2017). Muslim Daily Religiosity Assessment Scale (MUDRAS): A new instrument for Muslim religiosity research and practice. Psychology of Religion and Spirituality. https://doi.org/10.1037/ relooooo74.

Ontorael, R., Suhadak, \& Mawardi, M. K. (2017). Analysis Of The Influence Of External And Internal Environmental Factors On Business
The Effect of Muslim Religiosity and Innovation 
IQTISHADIA

13,2

Performance: A Study On Micro Small And Medium Enterprises (Msmes) Of Food And Beverage. Russian Journal of Agricultural and Socio-Economic Sciences. https://doi.org/10.18551/rjoas.2017-06.05.

Ortiz-Villajos, J. M., \& Sotoca, S. (2018). Innovation and business survival: A long-term approach. Research Policy. https://doi.org/10.1016/j. respol.2018.04.019.

Saleh Baqutayan, S. M. (2011). The Importance of Religious Orientation in Managing Stress. International Journal of Psychological Studies. https://doi.org/10.5539/ijps.v3n1p113.

Sarif, S. M. (2016). The influence of taqwa in sustainable capacity building. South East Asia Journal of Contemporary Business, Economics and Law.

Saroglou, V. (2010). Religiousness as a cultural adaptation of basic traits: A five-factor model perspective. Personality and Social Psychology Review. https://doi.org/10.1177/1088868309352322.

Shin, K., Park, G., Choi, J. Y., \& Choy, M. (2017). Factors affecting the survival of SMEs: A study of biotechnology firms in South Korea. Sustainability (Switzerland). https://doi.org/10.3390/su9010108.

Sitharam, S., \& Hoque, M. (2016). Factors affecting the performance of small and medium enterprises in KwaZulu-Natal, South Africa. Problems and Perspectives in Management. https://doi.org/10.21511/ ppm.14(2-2).2016.03.

Soininen, J., Puumalainen, K., Sjögrén, H., \& Syrjä, P. (2012). The impact of global economic crisis on SMEs: Does entrepreneurial orientation matter? Management Research Review. https://doi. org/10.1108/01409171211272660.

Sulistyo, H., \& Siyamtinah. (2016). Innovation capability of SMEs through entrepreneurship, marketing capability, relational capital and empowerment. Asia Pacific Management Review. https://doi. org/10.1016/j.apmrv.2016.02.002.

Tahir, I. R., \& Abdul, M. (2013). The Role of Religious Orientation in the Business Performance of Women Owned Firms: A Preliminary Study in Malaysia Halal Food Industry. The Macrotheme Review.

Thornhill, S. (2006). Knowledge, innovation and firm performance in highand low-technology regimes. Journal of Business Venturing. https:// doi.org/10.1016/j.jbusvent.2005.06.001.

Yu Cao. (2012). A survival analysis of small and medium enterprises (SMEs) in central China and their determinants. African Journal of Business Management, 6(10), 3834-3850. 